\title{
Jeotermal Kaynakların Tarımsal Sulama Suyu Kirliliği ve Kalitesi Üzerine Etkilerinin Belirlenmesi
}

\author{
Harun TORUNLAR ${ }^{1, *(D)}$ \\ Murat Güven TUĞAÇ' (D) \\ Gamze Depel² (D) Nevzat Dereköy² \\ 'Tarla Bitkileri Merkez Araștırma Enstitüsü Müdürlüğü, Ankara, \\ 2Toprak Gübre ve Su Kaynakları Merkez Araștırma Enstitüsü Müdürlüğü, Ankara
}

Dilek Kaya Özdoğan² (iD)

\begin{abstract}
*Sorumlu yazar e-mail (Corresponding author e-mail): htorunlar@hotmail.com
Geliș tarihi (Received): 11.10.2017

Kabul tarihi (Accepted): 16.07.2019

DOI: $10.21657 /$ topraksu. 654783
\end{abstract}

\section{Öz}

Bu çalıșmada; Ankara ili Ayaș ilçesinde bulunan jeotermal kaynakların kullanımlarından sonra ortaya çıkan jeotermal atık suların, bölgede tarımsal amaçlı sulama suyu olarak kullanılan İlhan çayına deșarjı sonrasında bu sularda yarattığı kirlenme ve kalitesinin değișmesi ile yetiștirilen tarımsal ürünler üzerinde olușturduğu kirlenme potansiyelinin belirlenmesi amaçlanmıștır.

Jeotermal sular, dere suları, jeotermal deșarj suları, yeraltı suları ve içme sularından alınan su örneklerine ait analiz değerleri, Su Kirliliği Kontrolü Yönetmeliği Teknik Usuller Tebliğinde belirtilen eșik değerler olmak üzere çeșitli uluslararası standartlar kullanılarak değerlendirilmiștir. Buğday, domates, șekerpancarı, havuç ve yonca'dan olușan bitki örneklerine ait analiz değerleri ise, Biyokonsantrasyon indeks değerlerine göre değerlendirilmiștir.

Sulama sezonu öncesi ve sonrası olmak üzere iki dönem halinde alınan su örneklerinde ağır metal ve iz elementlerden Arsenik (As); 26.93-234.57 $\mathrm{g} \mathrm{L}^{-1}$, Molibden (Mo); 17.3-67.4 $\mathrm{gg} \mathrm{L}^{-1}$, Bor (B); 2.58-8.74 mg l-1 olarak, su kalite parametrelerinden $\mathrm{Ec} ; 3120-7970 \mu \mathrm{cm}^{-1}$, pH; 8.6-9.3, klorür (Cl); 40.64-1 140.47 mg $~^{-1}$, sülfat (SO4); 675.34-5622.91 $\mathrm{mg} \mathrm{L}^{-1}$, ve toplam tuz konsantrasyonu 1210.24-5676,8 $\mathrm{mg} \mathrm{l}^{-1}$ olarak bulunmuștur. Bitkilerin farklı aksamlarından alınan örnekler için, makro-mikro besin elementleri ile ağır metal ve iz elementler açısından kirlenme potansiyelini ortaya koyan Biyokonsantrasyon indeks değerleri hesaplanmıștır. Değerlendirilmeler neticesinde çalıșma alanındaki sulama sularının V. Sınıf (zararlı) su kalitesinde olduğu ve sulama suyu kullanılabilirlik oranı olarak \% 33.3'lük bir orana sahip olduğu sonucuna varılmıștır.

Anahtar kelimeler : Bitki, jeotermal kaynaklar, kirlilik, sulama suları

\section{Assessing Impact of Geothermal Resources on Quality and Pollution of Agricultural Irrigation Waters}

\footnotetext{
Abstract

Wastewaters derived from the use of geothermals occurring in Ayas county (Ankara) where these are later discharged to IIIhan stream, which is used for irrigation. Pollution potential of the geothermal wastewaters on local agricultural products and pollution with impact on the water quality of the stream after the discharge was the main subject of this project.
} 
Analyses carried out on the water samples representing geothermal waters, streamwaters, geothermal discharge waters, ground waters and drinking waters were assessed according to the threshold values stated by Technical Principles Statement of Water Pollution Control Regulation and to various international standards. Analyses data of wheat, tomatoes, sugar beet, carrot, and clover samples were evaluated with respect to the bioconcentration index values.

In the water samples collected in two phases, before and after the irrigation season, heavy metal and trace elements including arsenic (As); $26.93-234.57 \mu \mathrm{g} \mathrm{L}^{-1}$, molibdenum (Mo); 17.3-67.4 $\mathrm{mg} \mathrm{L}^{-1}$, boron (B); 2.58-8.74 $\mathrm{mg} \mathrm{l}^{-1}$ were measured along with water quality parameters including Ec; $3120-$ $7970 \mu \mathrm{S} \mathrm{cm}{ }^{-1}, \mathrm{pH}$; 8.6-9.3, chloride (Cl); 40.64-1140.47 $\mathrm{mg} \mathrm{l}^{-1}$, sulfate (SO4); 675.34-5622.91 $\mathrm{mg} \mathrm{L}^{-1}$ and total salt concentration $1210.24-5676,8 \mathrm{mg} \mathrm{l}^{-1}$. For the samples taken from various parts of the plants, bioconcentration index values revealing pollution potential with respect to the macro-micro nutrition elements with heavy metal and trace elements were calculated. As a result of evaluations of the subject area waters, these are classified as $V$. Class (unsafe) water quality and it is concluded that their usability rate as irrigation water is 33.3\%.

Keywords: Plant, geothermal resources, pollution, irrigation waters

\section{GíRiș}

Günümüzde ülkelerin gelișmesi ve sürdürülebilir kalkınması üzerinde doğal kaynakların bilinçli ve kontrollü bir șekilde kullanıımasının etkisi büyüktür. Doğal kaynaklar hızla tükenirken, üretim ve tüketimden kaynaklı atıkların yeterli önlemler alınmadan doğaya bırakılması genel çerçevede çevre kirliliğinin olușmasına ortam sağlamaktadır. Fosilyakıtlara göre çevreye zararlı etkilerinin az olması alternatif enerji kaynaklarından biri olan jeotermal kaynakların önemini ve değerini arttırmaktadır. Fakat bu kaynakların kullanımı ve kullanımı sonrası çevreye bırakılması așamasında bazı problemlerin yașandığı görülmektedir. Jeotermal sular kullanıldıktan sonra bir bölümü yeniden yer altına enjekte edilmekte (reenjeksiyon), ancak önemli bir kısmı da doğal su yolları ile sulama, içme vb. amaçla kullanılan sulara karıșmaktadır. Buyüzden jeotermal sular, bu suların kalitesinin bozulmasına hatta kullanılamaz hale gelmesine sebep olabilmektedir (Eroğlu, 2008). Kullanıldıktan sonra doğada nehir veya bașka yüzey sularına bırakılan atık jeotermal sular bünyelerindeki element çeșitliliğinden dolayı içme ve sulama suları, tarım yapılan topraklar, bitki, insan ve hayvan sağlığı açısından büyük risk olușturmaktadır. Özellikle tarımsal sulamada kullanılamayacak bol miktarda element içeriğine sahip bu termal suların tarım alanlarına zarar vermesinin önlenmesi için bu suların kullanııdıktan sonra ortamdan uzaklaștırıması gerekir (Eșder, 1981). Alternatif enerji kaynaklarından biri olan jeotermal kaynakların bilinçsizce kullanımları ile birlikte çevre bilincinin gelișmesiyle toprak, su ve bitkilerde yarattığı ağır metal ve iz element kirliliği üzerinde yoğun araștırmalar yapılmıș ve bu parametrelerin çevre üzerindeki etkileri ortaya koyulmaya çalıșılmıștır.

Birkle ve Merkel (2000), yapmıș oldukları çalıșmalarında, 1994 Kasım ile 1996 Mayıs dönemleri arasında, Meksika'da Los Azufres jeotermal sahasının içindeki ve etrafındaki yüzey sularının ve sığ akiferlerin kirlendiğini tespit etmișlerdir. Jeotermal saha içinde olduğu gibi 10 km'ye varan mesafelerde de iz element derișimlerinde, özellikle $\mathrm{Fe}, \mathrm{Mn}, \mathrm{F}, \mathrm{B}$ ve As'te sürekli yüksek artıșlar gözlemlemișlerdir. B ve As için sırasıyla 125 ve $8 \mathrm{mg} \mathrm{L}^{-1}$ maksimum değerleri tespit etmișlerdir. Hipersalin jeotermal tuzlu suların boșalımının civarındaki toprakların tuzlanmasına, nehir suyunun civar bölgelerde içme ve sulama amaçlı kullanımı, toksit elementlerin insan besin zincirinde birikime neden olduğunu ve halkın sağlığını tehlikeye attığını tespit etmișlerdir.

Camgöz vd. (2010), İzmir, Seferihisar bölgesinde termal suların gözlendiği dört istasyonda aylık periyotlarda su örneklerinden radon aktivite konsantrasyonlarını ve kimyasal içeriklerini istatistiksel olarak incelemișlerdir. Ölçüm yapılan istasyonlarda canlılar için riskli düzeyde değișebilen radon aktivite konsantrasyonları tespit edilmiș, sulama suyu bakımından çalıșma alanındaki bütün jeotarmal suların $\mathrm{C}_{4} \mathrm{~S}_{4}$ sınıfında çok yüksek tuzlu ve sodyumlu sular sınıfında yer aldığını ve bu suların hiç bir șekilde içme ve tarımsal amaçlı sulamada kullanılamayacağını tespit etmișlerdir. 
Tarım arazileri üzerinde çeșitli kirletici unsurlara bağlı olarak olușan risklere dikkat çekmek ve risklerden bu alanları korumak amacıyla gerçekleștirilen bu çalıșma; Ankara ili Ayaș ilçesinde bulunan jeotermal kaynakların kullanımlarından sonra ortaya cılkan jeotermal atık suların bölgede tarımsal amaçlı sulama suyu olarak kullanılan İlhan çayına deșarjı sonrasında, bu sularda yarattığı kirlenme ve kalitesinin değișmesi ile yetiștirilen tarımsal ürünler üzerinde olușturduğu kirlenme potansiyelinin belirlenmesini amaçlamıștır.

\section{MATERYAL VE YÖNTEM}

\section{Çalıșma alanı}

Çalıșma alanı; Ankara iline ait Ayaș ilçesinin Akkaya, İlhanköy ve Uğurçayırı köyleri arasında bulunan İlhan ve Uğur çayları tarafından sulanan yaklașı 4645 hektar (ha) alana sahip sulu tarım arazilerinden olușmaktadır. Alan 529-780 metre (m) yükseklikleri arasında kod farkına sahip olup, hakim olan jeomorfolojik birimler vadi tabanı, vadi içi lokal sırtlar, yüksek eğimli ve drenajlı alanlar ile yüksek sırtlardan olușturmaktadır (Șekil 1).

Çalıșma alanında; sıcaklıkları 43,51 ve 51.5 C $^{\circ}$ arasında olan üç adet Cobanhamamı mevkisinde bulunan Ayaș içmece ve kaplıcaları, 58 ve 58.5 $\mathrm{C}^{\circ}$ lerde iki adet il özel idaresine ait jeotermal kaynak, 26.65, 31 ve $34 \mathrm{C}^{\circ}$ lerde üç adet Ayaș belediyesi ve özel sektöre ait jeotermal kaynaklar bulunmaktadır.

\section{İklim verileri}

Bir bölgenin iklim koșulları tarımsal faaliyetlerin sürdürülmesinde sulamaya duyulan gereksinimi etkilemektedir. Alanının büyük çoğunluğunun sulu tarım olarak kullanıldığı çalıșma alanından uygun dönemlerde su örnekleri alınabilmesi için proje alanının sulama durumunu yansıtan yağıș- potansiyel buharlașma değișimi verisinin elde edilmesinde iklim verileri materyal olarak kullanılmıștır. Bunun için Meteoroloji Genel Müdürlüğünden temin

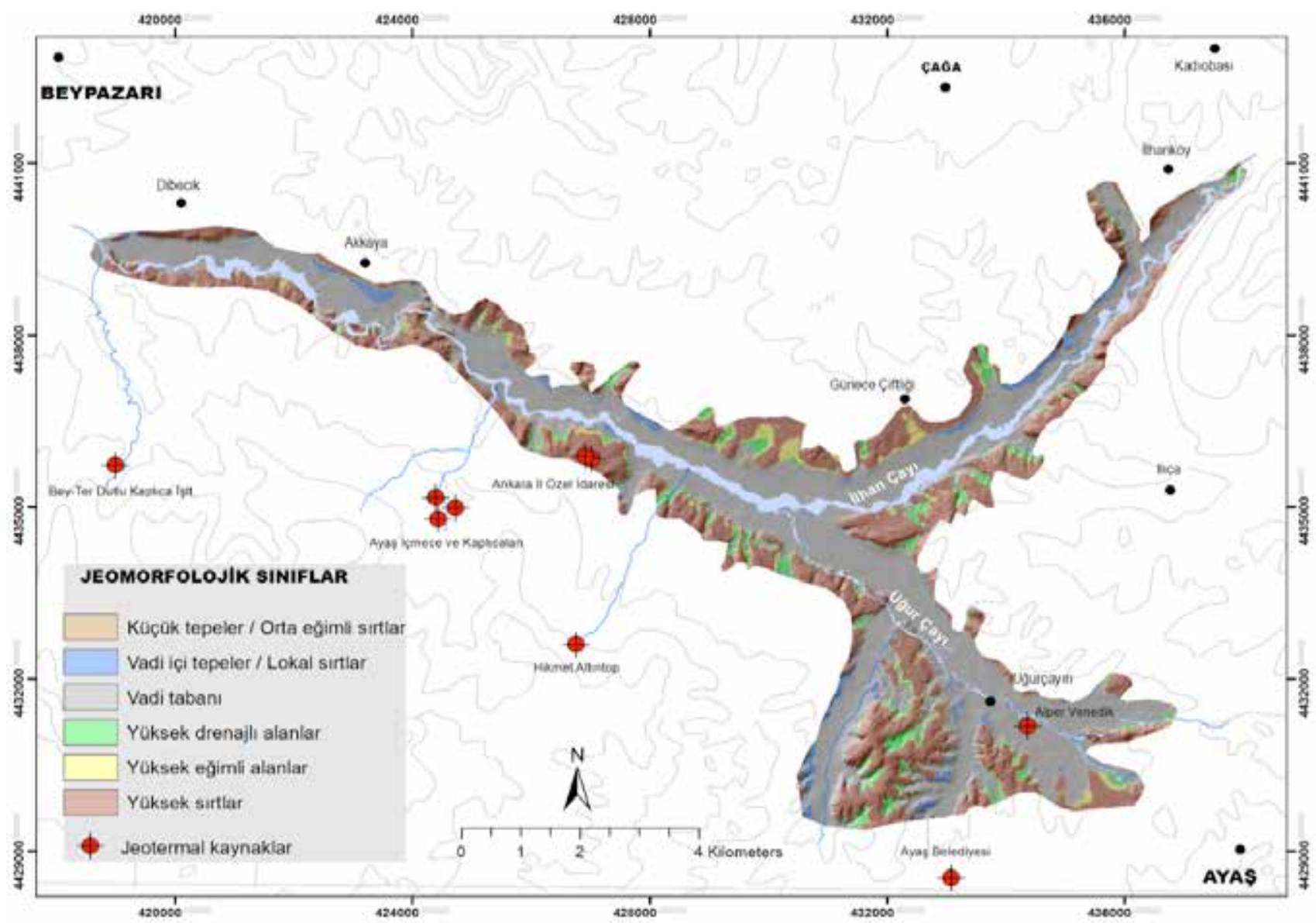

Șekil 1. Çalıșma alanı

Figure 1. Study area 
edilen Ayaș ve çevre istasyonlarından 19752012 yılları arasında ölçülen yağıș, maksimum sıcaklık, minimum sıcaklık, ortalama sıcaklık, rüzgar hızı, güneșlenme süresi ve nispi nem parametrelerinden olușan uzun yıllar aylık iklim verilerinden faydalanılmıștır.

\section{Su ve bitki örnekleri}

Çalıșma alanı içerisinde araziden toplanan su ve bitki örnekleri ile bu örneklere ait analiz değerleri, çalıșmada kullanılan en önemli materyallerden birini olușturmuștur. Sulardaki mevsimsel değișimlerin etkisinin araștırıması için çalıșma bölgesinin tarımsal sulama sezonları dikkate alınmıș ve buna göre su örnekleri 2014 yılı sulama sezonu sonrası ile 2015 yılı sulama sezonu öncesi ve sulama sezonu sonrası olmak üzere üç dönem halinde alınmıștır. Alınan su örnekleri için laboratuvarda yapılan analiz türleri Çizelge I'de verilmiștir.
Bitki örneklemeleri için, çalıșma alanının ürün desenini temsilen yöre için ekonomik öneme sahip, en çokyetiștirilen ve tüketilen beș temel ürün (buğday, domates, havuç, șeker pancarı ve yonca) seçilmiștir. Bitkilerin farklı aksamlarından alınan örnekler için yapılan analiz türleri Çizelge Z'de verilmiștir.

\section{YÖNTEM}

\section{Su örneklerinin alınması}

Su örneklerinin alınma zamanını belirleyebilmek için sulardaki mevsimsel değișimlerin etkisi gözönüne alınarak, öncelikle çalıșma alanının tarımsal sulama sezonu belirlenmiștir. Bu sezonu belirlerken çalıșma alanının su bilançosu, iklim verileri kullanılarak elde edilmiștir (Çizelge 3). 1975-2012 yıllarını kapsayan uzun yıllar aylık ortalama sıcaklık, yağıș ve potansiyel buharlașma verileri üretilmiș, potansiyel buharlașma verisinin üretilmesinde FAO Penman - Monteith metodu kullanıımıștır (Allen vd., 1998).

Çizelge 1. Su örnekleri ve laboratuvar analiz türleri

Table 1. Water samples and types of laboratory analysis

\begin{tabular}{cl}
\hline Su örneklemeleri & \multicolumn{1}{c}{ Laboratuvar analizleri } \\
\hline Dere suları & - Sıcaklık, EC $\left(\mathrm{dS} \mathrm{m} \mathrm{m}^{-1}\right), \mathrm{PH}, \mathrm{NO} 3\left(\mathrm{mg} \mathrm{l}^{-1}\right), \mathrm{NH} 4\left(\mathrm{mg} \mathrm{l}^{-1}\right)$ \\
Jeotermal sular & - Sodyum Absorpsiyon Oranı \\
Atık (deșarj) suları & - Değișebilir Sodyum Yüzdesi $(\mathrm{ESP})$ \\
Yeraltı suları & - Çözünebilir iyonlar $\left(\mathrm{Ca}^{+2}, \mathrm{Mg}^{+2}, \mathrm{Na}^{+}, \mathrm{K}^{+}, \mathrm{CO}^{-2}{ }_{3}, \mathrm{HCO}^{-3}, \mathrm{Cl}^{-}, \mathrm{SO}^{-2}{ }_{4}\right)$ \\
İçme suları & - B ve P \\
\hline
\end{tabular}

Çizelge 2. Bitki örnekleri ve laboratuvar analiz türleri

Table 2. Plant samples and types of laboratory analysis

\begin{tabular}{ccc}
\hline Bitki türleri & Bitki aksamları & Laboratuvar analizleri \\
\hline Buğday & Yaprak-Kök & \\
Domates & Yaprak & Mg, Ca, K, Na, B,P, Fe, Zn, \\
Șeker pancarı & Yaprak-Kök & Mn, Cu, S, Cd,Co,Cr, Ni, Pb, As, N,Mo \\
Havuç & Yaprak-Kök & \\
Yonca & Yaprak-Gövde & \\
\hline
\end{tabular}

Çizelge 3. Çalıșma alanına ait su bilançosu

Table 3. Water budget for study area

Ocak Șubat Mart Nisan Mayıs HaziranTemmuzAğustos Eylül Ekim Kasım Aralık Yıllık

\begin{tabular}{cccccccccccccc}
\hline Ort. Sıc. & 1.1 & 2.8 & 7.0 & 12.4 & 17.4 & 21.5 & 24.8 & 24.4 & 20.0 & 14.0 & 7.5 & 3.0 & 13.0 \\
Yağıș (mm) & 48.0 & 33.4 & 33.8 & 48.9 & 42.5 & 29.4 & 14.0 & 14.1 & 12.6 & 28.3 & 37.6 & 54.0 & 396.6 \\
$\begin{array}{c}\text { PET (Potansiyel } \\
\text { Buharlașma) }\end{array}$ & 17.33 & 25.73 & 50 & 76.63 & 111.35 & 137.85 & 162.73 & 144.57 & 95.13 & 53.5 & 25.55 & 16.69 & 917.06 \\
$\begin{array}{c}\text { Su Fazlası (mm) } \\
\begin{array}{c}\text { Bitkiler için } \\
\text { faydalı su yedeği }\end{array}\end{array}$ & 100 & 100 & 83.8 & 56.07 & 0 & 0 & 0 & 0 & 0 & 0 & 12.05 & 49.36 \\
\hline
\end{tabular}




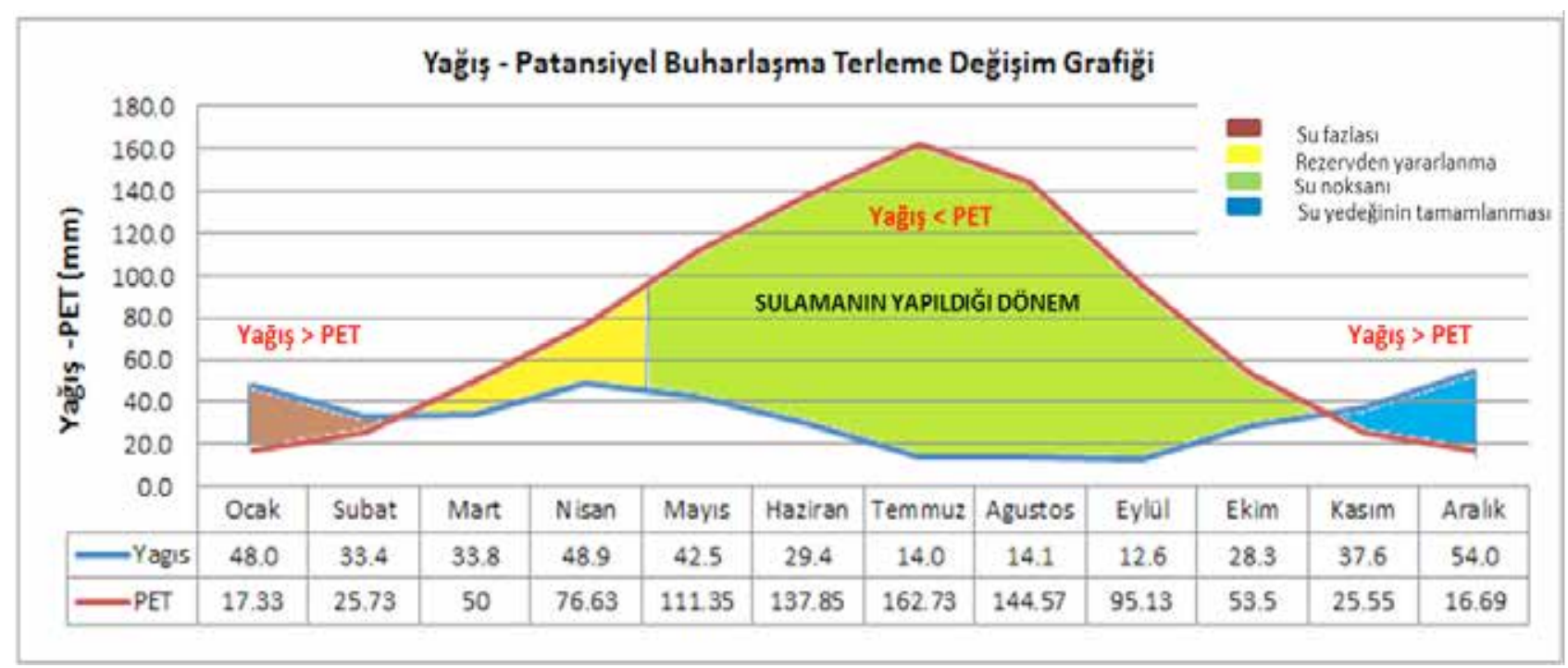

Șekil 2. Çalıșma alanının yağıș-potansiyel buharlașma terleme değișim grafiği

Figure 2. Precipitation - potential evaporation sweating change graph of the study area

Aylık bazda Yağıș-Potansiyel buharlașma farklarının hesaplanmasından elde edilen bitkiler için faydalı su yedeği değerlerinin sıfır (0) çıktığı aylar sulama ihtiyacının görüldüğü dönemleri yansıtmaktadır. Buna göre bölgenin tarımsal sulama dönemi Mayıs ayı bașı ile Ekim ayı sonu olarak belirlenmiștir. Aynı veriler kullanılarak, üretilmiș yağıș-potansiyel buharlașma terleme değișim grafiği göz önüne alınarak su örnekleme tarihleri belirlenmiștir (Șekil 2).

2014 yılı sulama sezonu sonrası ile 2015 yılı sulama sezonu öncesi ve sonrası dönemlerini kapsayan 10 Ekim 2014, 29 Nisan ve 20 Ekim 2015 tarihlerinde 1.5 litrelik plastik șișelere konularak su örnekleri alınmıștır. Toplamda 51 adet su örneği alınmıș olup (Șekil 3), su örneklerinin alınmasında, bir önceki dönemde alınan noktalardan alınmasına özen gösterilmiștir.

\section{Bitki örneklerinin alınması}

Bitkilere ait örneklemeler yapılırken, bitki gelișim dönemleri göz önüne alınmıș ve her bitki için farklı tarih, bitki aksamı ve numune sayısına göre 5 kg'ık kağıt torbalara konulacak șekilde örnekler alınmıștır (Çizelge 4).

Çalıșma alanı içerisinde buğdaydan 11 adet yaprak 11 adet kök, domatesten 16 adet yaprak, havuçtan 7 adet yaprak 7 adet kök, șeker pancarından 5 adet yaprak 5 adet kök, yoncadan 8 adet yaprak 8 adet gövde olmak üzere 47 noktadan toplam 78 adet bitki örneklemesi yapıımıștır (Șekil 3).

Çizelge 4. Bitki örneklerinin alındığı dönem, kısım ve miktarları

Table 4. Period, parts and quantities of collected plant samples

\begin{tabular}{|c|c|c|c|c|c|}
\hline Tarih & Bitki Türü & Bitki Aksamı & Gelișme Dönemi & Numune Alınan Kısım & Adet \\
\hline 15.05 .2015 & Buğday & Yaprak Kök & $\begin{array}{l}\text { Bașaklanma } \\
\text { Öncesi }\end{array}$ & Tepeye en yakın olgunlașmıș 4 yaprak & $40-50$ \\
\hline 25.06 .2015 & Domates & Yaprak & $\begin{array}{l}\text { Çiçeklenme öncesi } \\
\text { veya sırasında }\end{array}$ & $\begin{array}{c}\text { Büyüme ucundan itibaren 3. veya } 4 . \\
\text { yaprak }\end{array}$ & $20-25$ \\
\hline 13.07 .2015 & $\begin{array}{l}\text { Șeker Pan- } \\
\text { carı }\end{array}$ & Yaprak Kök & Mevsim ortası & $\begin{array}{l}\text { Merkezdeki en genç yaprak ile } \\
\text { dıștaki en yașlı yaprak arasında kalan } \\
\text { gelișimini tamamlamıș genç yapraklar }\end{array}$ & $30-40$ \\
\hline 05.10 .2015 & Havuç & Yaprak Kök & $\begin{array}{l}\text { Kök ve baș } \\
\text { irileșmeden önce }\end{array}$ & Olgunlașmıș en genç yaprak ve sapı & $20-30$ \\
\hline 20.10 .2015 & Yonca & Yaprak Gövde & $\begin{array}{l}\text { Çiçeklenme öncesi } \\
\text { veya sırasında }\end{array}$ & $\begin{array}{c}\text { Bitki boyunun tepeden itibaren 1/3 } \\
\text { olgunlasmıs yaprak ayası }\end{array}$ & $40-50$ \\
\hline
\end{tabular}




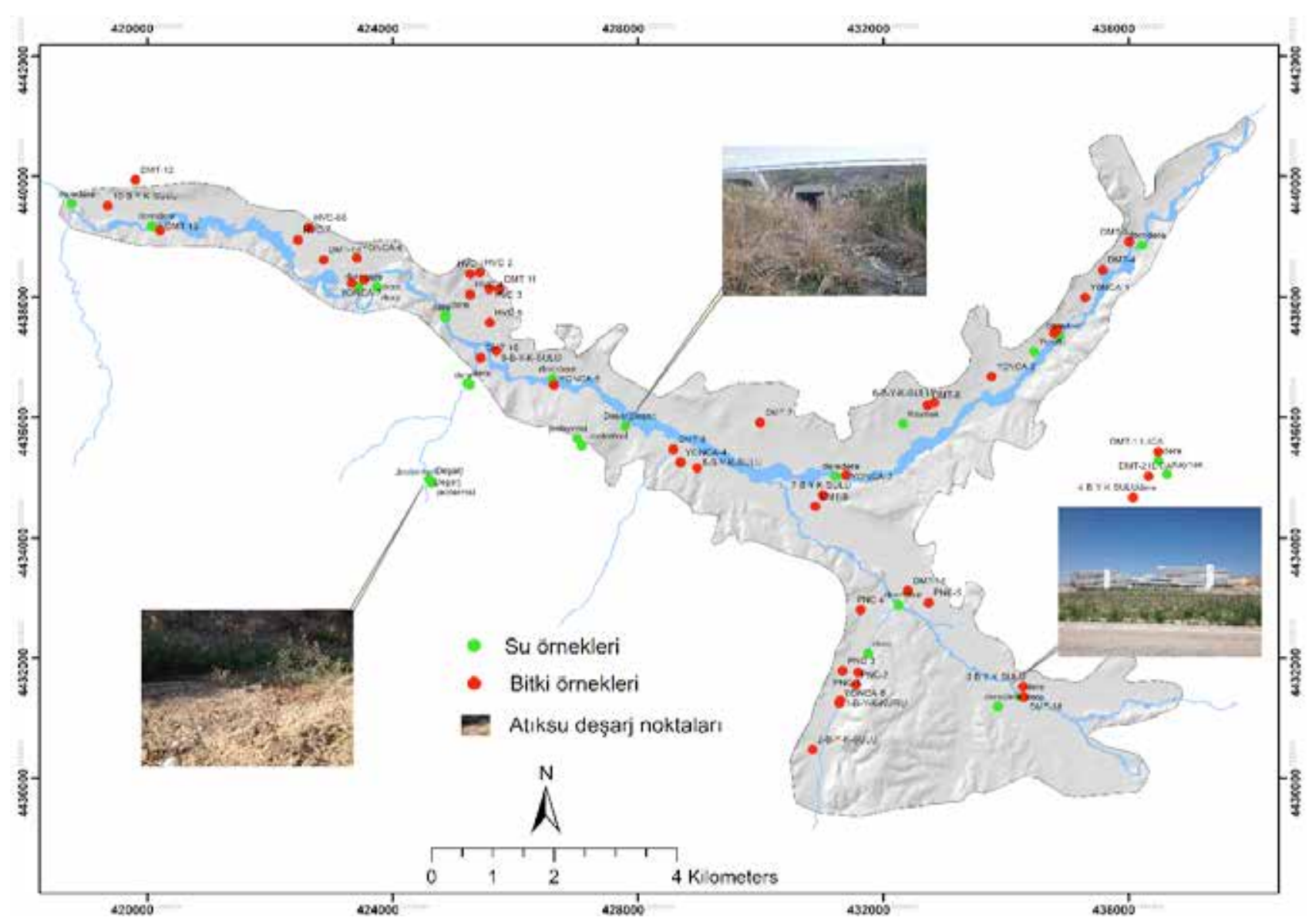

Șekil 3. Su ve bitki örneklerinin alındığı noktalar

Figure 3. Points of collected water and plant samples

\section{Su analizlerinin değerlendirilmesi}

Canlı hayatının devamını sağlamada temel unsur olan su, doğal kaynakların en önemlilerinden birisidir. Suyun kalitesinin ve ortamında doğal dengesinin bozulması su kirliliği olarak kabul edilmektedir. Bașlıca kullanım yerleri tarım ve endüstri alanlarıyla evsel gereksinimler olan suyun, potansiyel kullanımını kalitesi belirlemektedir (Akman vd., 2000). Yüzey ve yeraltı su kaynaklarımızın kirlenmesine sebep olan farklı faktörler yer alırken bu faktörlerden biri de artan nüfus ve sanayileșmeye bağlı olarak ortaya çıan atık sulardır. Özellikle tarımsal amaçlı kullanılan suların kirlenmesi tarımsal faaliyetlerde kalitenin azalmasına sebep olmaktadır. Çalıșma alanındaki jeotermal atık suların etkisine bağlı olarak farklı amaçlar için (sulama, içme vb.) kullanılan suların kirlenme ve kalitelerindeki değișimlerinin ortaya konulması amacıyla analizlerden elde edilen veriler değerlendirilmeye çalıșılmıștır. Değerlendirmeler yapilırken çalıșma alanı içerisinde güney- doğu, kuzey-batı doğrultusunda dağılım gösteren jeotermal kaynakların etkisini ortaya koyabilmek için, bu jeotermal kaynakların etkilediği alandaki su örnekleriyle, etkisinden uzak alanlardaki su örnekleri ayrı ayrı değerlendirimiș ve sonuçlar karșılaștırılmıștır. Suların tarımsal sulama suyu kalite sınıflarının belirlenmesinde 7 Ocak 1991 tarihli ve 20748 sayılı Resmî Gazetede yayınlanmıș olan Su Kirliliği Kontrolu Yönetmeliği Teknik Usuller Tebliği'nde belirtilen su kalite parametreleri eșik değerleri referans olarak kullanılmıștır (Anonim, 1991). İçme sularının değerlendirilmesinde TS266 standart değerleri ile Avrupa Çevre Ajansı (USEPA) ve Dünya Sağlık Örgütü (WHO) verileri kullanıımıștır. Yine sulama sularında ağır metal ve iz elementlerin izin verilebilen maksimum sınır değerlerinin belirlenmesinde (Ayers ve Westcot, 1989), (National Academy of Science, 1972) ile 31 Aralık 2004 tarihli ve 25687 sayılı Resmi gazetede yayınlanmıș olan Su Kirliliği Kontrolu Yönetmeliği / Kıta içi su kaynaklarının sınıflarına göre kalite kriterleri eșik değerleri referans bilgi olarak kullanılmıștır (Anonim, 2004). 


\section{Bitki analizlerinin değerlendirilmesi}

Bitkiler gelișip fizyolojik dönemlerini tamamlamada, gereksinim duydukları çeșitli elementleri kolayca topraktan ve sudan kökleri vasıtasıyla almaktadırlar (Okçu vd., 2009). Bitkide bulunan bu elementlerin dıșardan alındığı görüșü oldukça yaygındır (Brohi vd., 1994). Bundan dolayı bitki örneklerinde yapılan analizlerden elde edilen sonuçlara göre, doğada bulunan bütün elementleri bitki dokularında bulmak mümkündür. Bitkiler kendilerine yarayıșlı besin elementlerinin yanında, ağır metal ve iz elementlerini bünyelerine farklı yollarla alabilmektedirler. Bu yollardan en önemlisi köklerde katyon değișimi yoluyla alınmasıdır (Brooks, 1983). Aynı zamanda bitkilerin bu elementleri bünyelerine alabilme yeteneği

Çizelge 5. Jeotermal ve deșarj sularının tarımsal sulama suyu kalite sınıfları

Table 5. Agricultural irrigation water quality classes of geothermal and discharge waters

Kalite kriterleri
2014 SULAMA SEZONU SONRASI Jeotermal / Deșarj suları
2015 SULAMA SEZONU

ÖNCESI

Jeotermal / Deșarj suları
2015 SULAMA SEZONU SONRASI Jeotermal / Deșarj suları

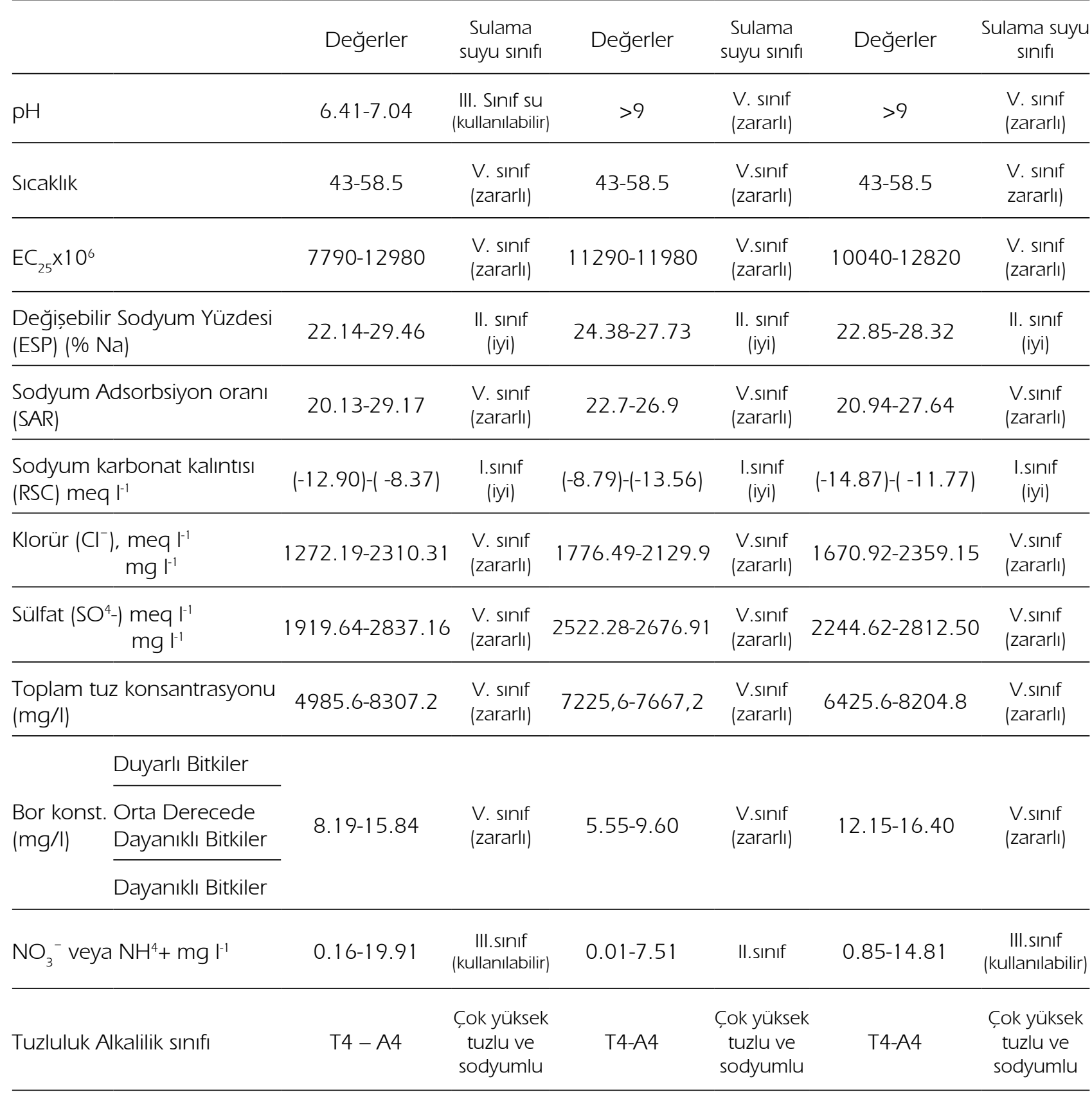


mevsime, iklime, toprak koșullarına ve bitki türlerine bağlı olarak oldukça değișkendir. Her bitkinin element içeriği ve elementlere karșı toleransı farkııdır (Dudka vd., 1995). Bundan dolayı, bu çalıșmada seçilen her bir bitki türü üzerinde olası ağır metal ve iz element birikimlerinin olup olmadığını ortaya koyabilmek için, bitki besin elementleri ile ağır metal ve iz elementlerin bitkilerdeki fazlası, zararlı (toksit) olabilecek seviyelerinin bilinmesi gerekmiștir. Bunun için analizi yapılan her bir elementin ilgili bitki için toksitlik sınır değerleri, yapıımıș çalıșmalardan elde edilen literatür bilgilerinin derlenmesiyle belirlenmiștir. Bitkiler üzerinde görülen kirlenme potansiyelinin belirlenmesinde biyokonsantrasyon faktörü (BKF) değerlerinden yararlanılmıștır. Biyokonsantrasyon faktörü, bitkinin etrafındaki yüzey ve yeraltı sularından veya topraktan elementleri bünyesine alma derecesini gösteren bir faktördür (Nguyen vd., 2005). Bitki bünyesindeki elementin birikim kapasitesini belirlemek için kullanılan biyokonsantrasyon faktörü;

formülü kullanılarak hesaplanmıștır. $B K F=\frac{S_{B}}{S_{E}}$

$S_{B}$ : bitki bünyesinde analizle ölçülen element konsatrasyon değeri,

$S_{E}$ ise ilgili elementin o bitki bünyesinde bulunması gereken maksimum eșik değerini göstermektedir.

Seçilen her bir bitki türü için Eșitlik 1 kullanılarak bitki bünyesinde ölçülen element konsatrasyonu değerleri normalize edilmiș ve biyokonsantrasyon faktör grafiklerinin olușturulması için birleștirilmiș biyokonsantrasyon faktörü indeks değerleri (BBKF) hesaplanmıștır. Bunu hesaplarken;

formülü kullanılmıștır.

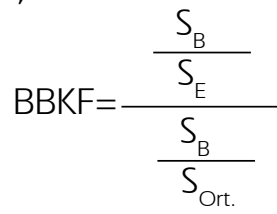

$S_{\text {Ort }}$ : bitkide ilgili elementin $n$ sayıda ölçülen değerlerin ortalamasını göstermektedir.

\section{BULGULAR VE TARTIȘMA}

\section{Su analizlerinin değerlendirilmesinden elde edilen bulgular}

Su örneklerine ait analiz sonuçlarının değerlendirmeleri yapılırken her su grubu kendi içinde değerlendirilmiș, özellikle sulama suyu olarak kullanılan dere suları ise jeotermal kaynakların çalıșma alanı içerisindeki genel konumlarına bağlı olarak, jeotermallerin etkisi altında ve etkisi altında bulunmayan sular olarak iki grup șeklinde değerlendirilmiștir. Buna göre; Jeotermal ve deșarj sular ile dere sularının tarımsal sulama suyu kalite sınıfları Çizelge 5 ve çizelge 6 olarak verilmiștir.

Sulara ait kalite parametrelerinin analiz değerleri çizelgelerde maksimum ve minimum veri aralığı olarak verilmiștir. Bu suların tarımsal sulama suyu amacıyla kullanılabilirlik oranları tespit edilmiș olup dönem ve gruplandırımıș sular bazında Çizelge 7'de yüzde değer olarak belirtilmiștir.

Çalıșma alanındaki jeotermal kaynaklar, deșarj suları ve dere suları, bünyelerinde izin verilebilen maksimum ağır metal ve toksit element konsantrasyonları göz önüne alınarak değerlendirilmiș ve elde edilen bulgular çizelge 8'de belirtilmiștir. Çizelge de sadece eșik değerin üzerindeki elementler verilmiștir.

Halk arasında tedavi amaçlı içilerek kullanılan jeotermal kaynak suları ile yine evlerden alınan içme suları; TS266, ABD Çevre Koruma Ajansı (USEPA) ve Dünya Sağlık Örgütü (WHO)'a ait eșik değerler kullanılarak değerlendirilmiștir. Değerlendirmelerde WHO'nun 1993 yllında ve USEPA'nın ocak 2001 yılında yayınladıkları bildiriler ile içme sularında bulunabilecek en yüksek arsenik (As) miktarı 0,05 $\mathrm{mg} \mathrm{L}^{-1}$ den 0,01 $\mathrm{mg} \mathrm{L}^{-1}$ değerine indirilmesi gözönüne alınmıș ve Çizelge 9 elde edilmiștir.

\section{Bitki analizlerinin değerlendirilmesinden elde edilen bulgular}

Bitkianalizlerineaitverilerindeğerlendirilmesinden elde edilen bulgular grafik șeklinde verilmiștir. Söz konusu bitkiler için kirlenme potansiyellerinin belirlenmesinde kullanılan biyokonsantrasyon indeks değerlerinin elde edilmesi için, her bir bitki için element bazında toksitlik sınır değerleri; yapıımıș çalıșmalardan elde edilen bilgilerinin derlenmesiyle belirlenmiștir (Çizelge 10). Toksitlik sınır değerleri kullanılarak elde edilen biyokonsantrayon indeks değerleri, birleștirilmiș biyokonsantrasyon indeks değerlerine dönüștürülerek her bitki için bitkinin ilgili aksamlarında element bazında birikim düzeyleri grafiklendirilmiștir (Șekil 4). Grafiklere göre indeks değeri 1 (Bir) 'in üzerinde olan her bir elementin o bitki türü için kirlenme boyutunda olduğu kabul edilmiștir. 


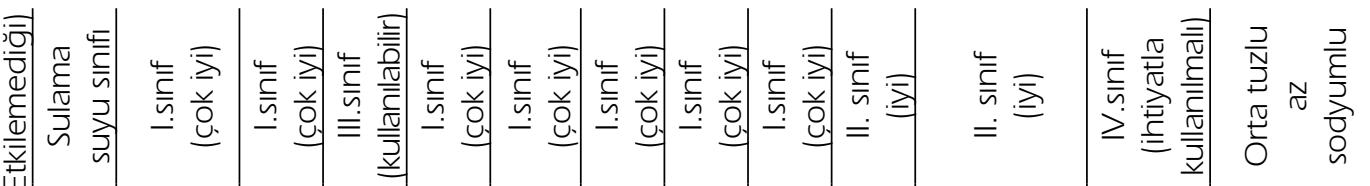

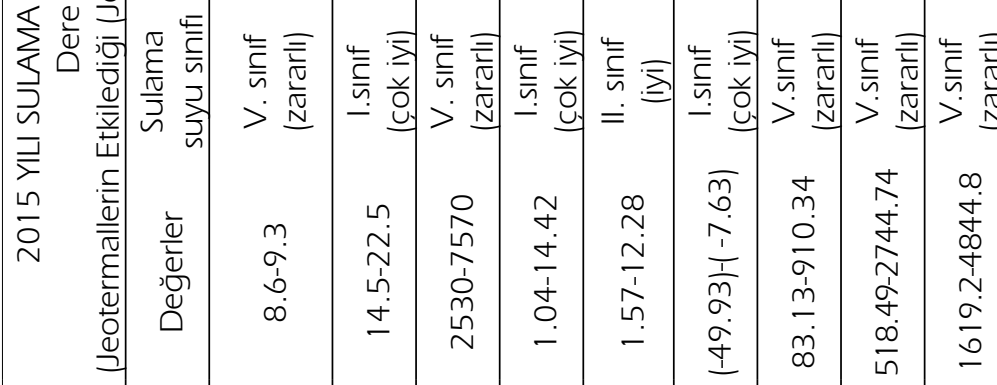

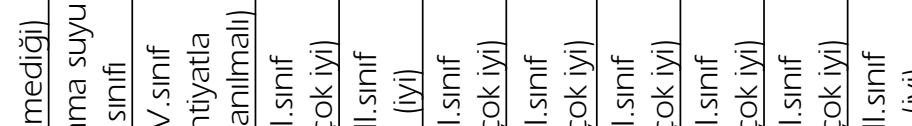

$\overline{\bar{n}}$

咅

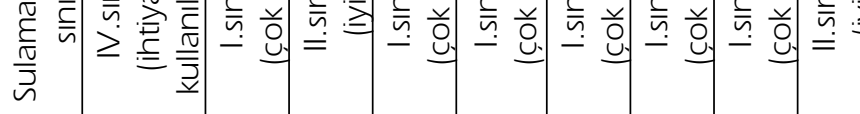
$\sum_{0}$

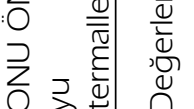

岀会苞

$\sum$ 河

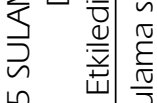

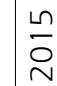

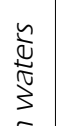

단.

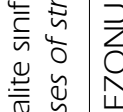

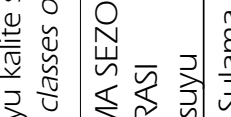

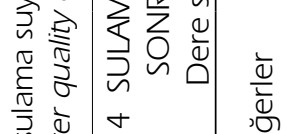

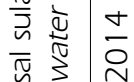

密恋

吾

玆

ปัข

0
0
0.0
0
0

产高
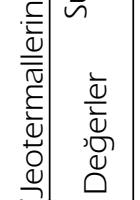

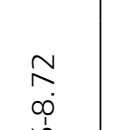

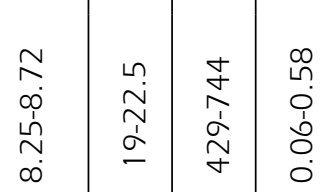

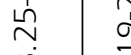

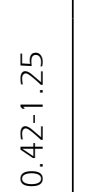

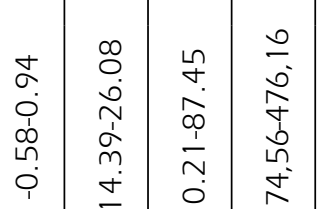

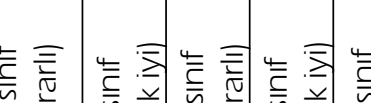

(1)

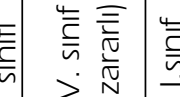

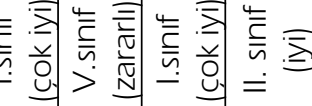

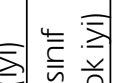

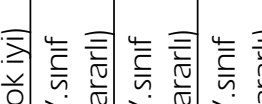

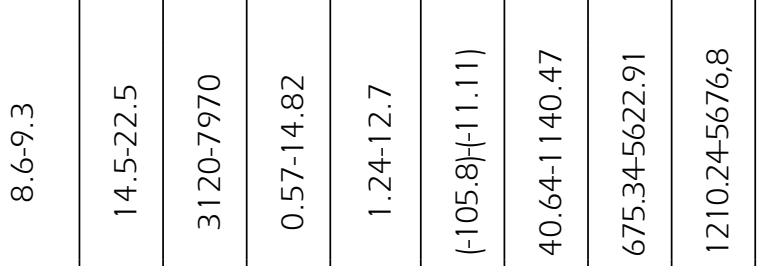

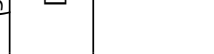

言

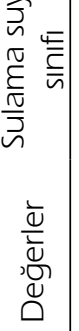

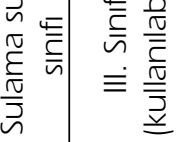

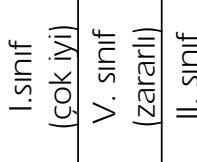

$\underset{\substack{n \\ \infty}}{\substack{1 \\ \infty}}$

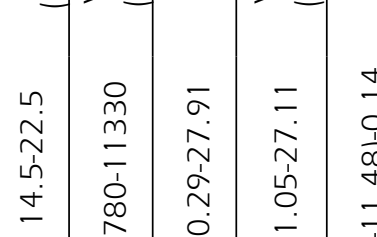

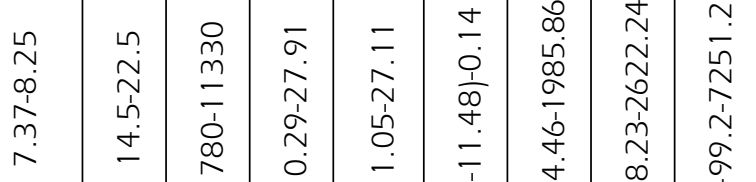

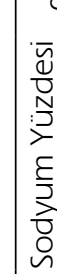

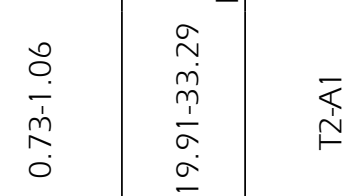

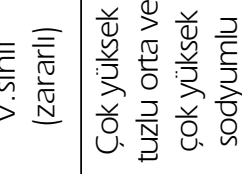

政

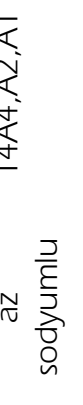


Çizelge 7. Çalıșma alanındaki suların sulama suyu kullanılabilirlik oranları

Table 7. Irrigation water availability rates of the study area waters

\begin{tabular}{|c|c|}
\hline \multicolumn{2}{|c|}{2014 yılı sulama sezonu sonrası } \\
\hline Sular & Sulama Suyu Kullanılabilirlik Oranı (\%) \\
\hline Jeotermal/Deșarj suları & 33.3 \\
\hline Dere suyu & 41.6 \\
\hline \multicolumn{2}{|c|}{2015 yılı sulama sezonu öncesi } \\
\hline Sular & Sulama Suyu Kullanılabilirlik Oranı (\%) \\
\hline Jeotermal/Deșarj suları & 25 \\
\hline Dere suyu (jeotermal Suların Etkilediği) & 41.6 \\
\hline Dere suyu (Jeotermal Suların Etkilemediği) & 83.3 \\
\hline \multicolumn{2}{|c|}{2015 yılı sulama sezonu sonrası } \\
\hline Sular & Sulama Suyu Kullanılabilirlik Oranı (\%) \\
\hline Jeotermal/Deșarj suları & 25 \\
\hline Dere suyu (jeotermal Suların Etkilediği) & 33.3 \\
\hline Dere suyu (Jeotermal Suların Etkilemediği) & 91.6 \\
\hline
\end{tabular}

Çizelge 8. Çalıșma alanındaki sularda izin verilebilen maksimum ağır metal ve toksit element konsantrasyon değerleri Table 8. Maximum heavy metal and toxic element concentration values allowed in the study area waters

\begin{tabular}{|c|c|c|c|c|c|c|}
\hline \multicolumn{3}{|c|}{2014} & \multicolumn{4}{|c|}{2015} \\
\hline Nokta No & $\operatorname{Mo}\left(\mu g L^{-1}\right)$ & B (ppb) & Nokta No & $\operatorname{Mo}\left(\mu \mathrm{L}^{-1}\right)$ & As $\left(\mu g L^{-1}\right)$ & B (ppb) \\
\hline $\mathrm{J} 1$ & 52.9 & 13.47 & Kaynak-1 & 29.22 & 234.57 & 0.55 \\
\hline$J 2$ & 17.3 & 15.84 & Dere-15 & 4.83 & 35.65 & 0.73 \\
\hline$D_{s j} 1$ & 31.0 & 15.23 & Dere-6 & 4.97 & 28.16 & 0.8 \\
\hline$D_{s j} 2$ & 36.2 & 8.19 & Dere-5 & 4.48 & 26.93 & 0.78 \\
\hline$D_{s j} 3$ & 29.6 & 14.46 & Kaynak-2 & 9.17 & 31.06 & 0.83 \\
\hline Derel & 52.7 & 14.66 & Dere-4 & 5.05 & 30.58 & 1.06 \\
\hline Dere2 & 52.9 & 1.78 & T2-Dsj & 7.88 & 82.00 & 16.4 \\
\hline Dere3 & 67.4 & 1.96 & Dere-7 & 7.99 & 51.13 & 2.6 \\
\hline Dere4 & 39.2 & 0.25 & Dere-8 & 8.86 & 47.26 & 2.77 \\
\hline Dere5 & 67.0 & 2.56 & Dere-9 & 7.76 & 51.18 & 2.73 \\
\hline \multirow[t]{10}{*}{ Dere6 } & 51.9 & 2.61 & Dere-10 & 8.41 & 54.78 & 2.93 \\
\hline & & & Dere-11 & 7.59 & 49.16 & 2.71 \\
\hline & & & Dere-12 & 7.43 & 51.70 & 2.68 \\
\hline & & & Dere-13 & 13.24 & 28.50 & 8.74 \\
\hline & & & T1-Icm & 11.33 & 45.30 & 12.15 \\
\hline & & & T1-Dsj & 14.51 & 43.35 & 0.00 \\
\hline & & & $\mathrm{T} 2-\mathrm{Htt}$ & 4.42 & 52.70 & 12.15 \\
\hline & & & Dere-3 & 19.80 & 94.24 & 3.68 \\
\hline & & & Dere-2 & 16.89 & 65.26 & 2.58 \\
\hline & & & Dere-1 & 26.90 & 42.26 & 4.01 \\
\hline
\end{tabular}


Çizelge 9. Çalıșma alanındaki içme sularının arsenik ve bor konsantrasyon değerleri

Table 9. Arsenic and boron concentration values of drinking waters in study area

\begin{tabular}{ccccc}
\hline Örnekler & \multicolumn{2}{c}{ Bor $\left(\mathrm{mg} \mathrm{L}^{-1}\right)$} & \multicolumn{2}{c}{ Arsenik $\left(\mu \mathrm{L} \mathrm{L}^{-1}\right)$} \\
\hline Je-1-lcm & Ölçülen değer & İin verilen mak. değer & Ölçülen değer & İzin verilen mak. değer \\
Dsj-1-Icm & 12.15 & & 43.35 & \\
Kaynak-1 & 16.40 & 2 & 43.35 & 10 (0.01 ppm) \\
Kaynak-2 & 0.55 & & 234.37 & \\
\hline
\end{tabular}

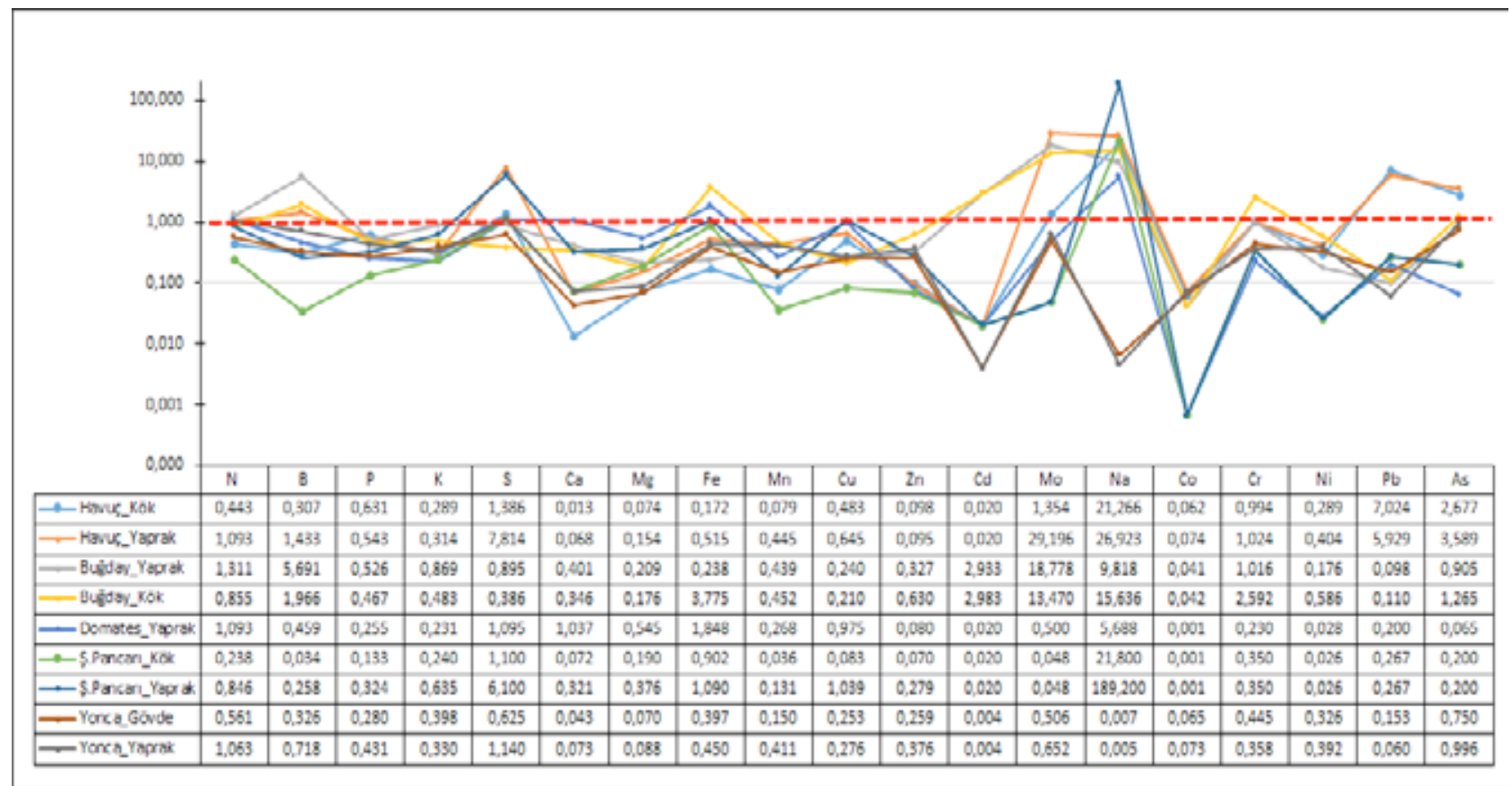

Șekil 4. Bitkilerin birleștirilmiș biyokonsantrasyon indeks değer ve grafikleri

Figure 4. Consolidated bioconcentration index values and graphs of plants 


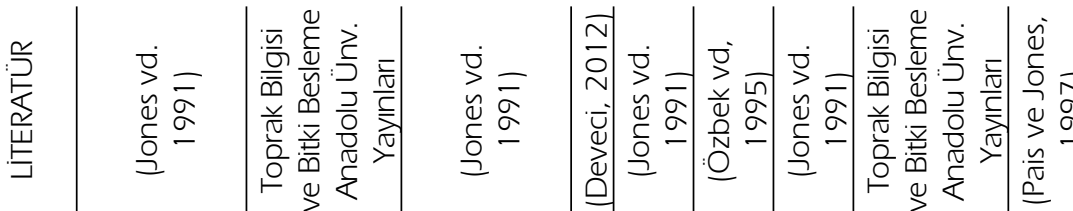

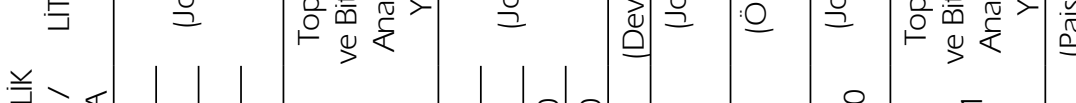

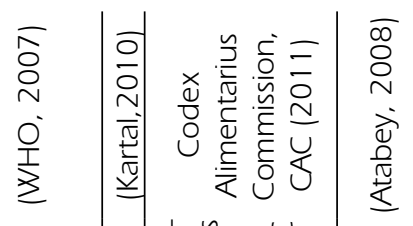

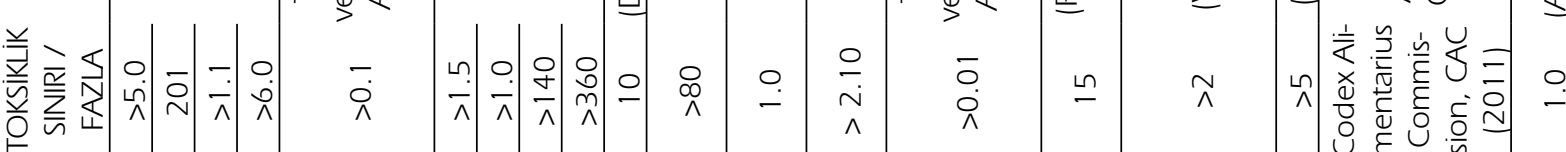

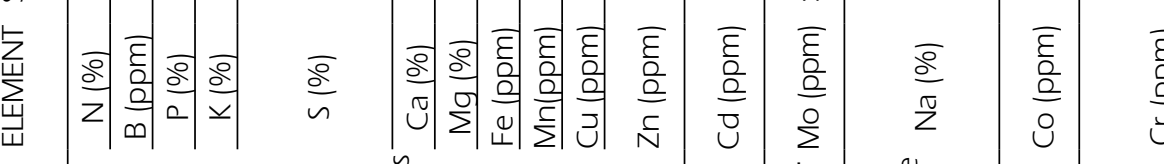

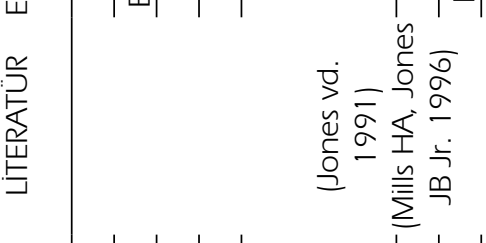

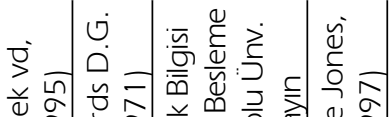

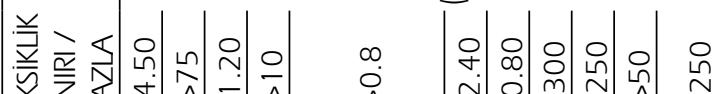

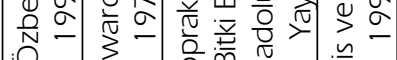

:

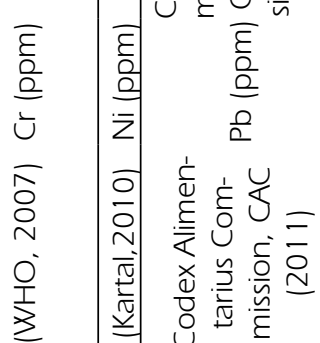

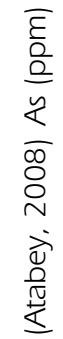

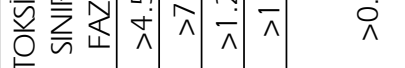

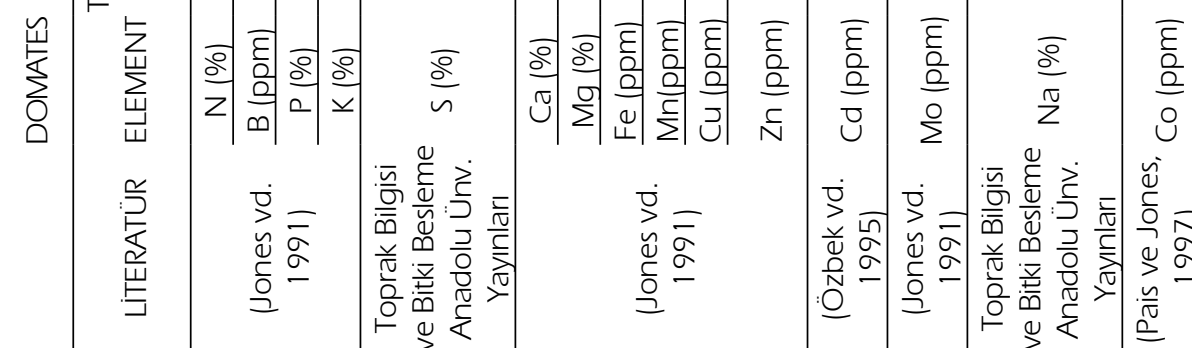

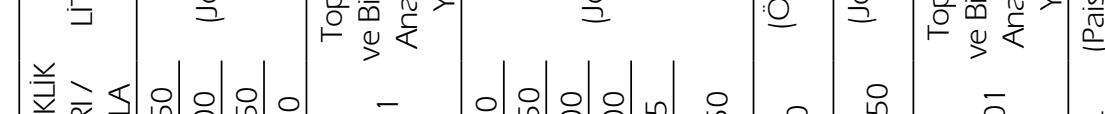

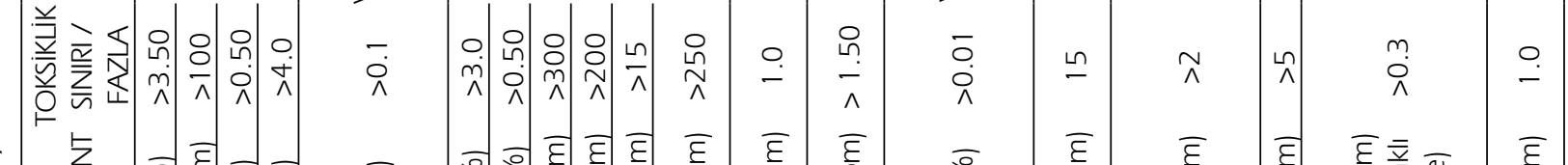

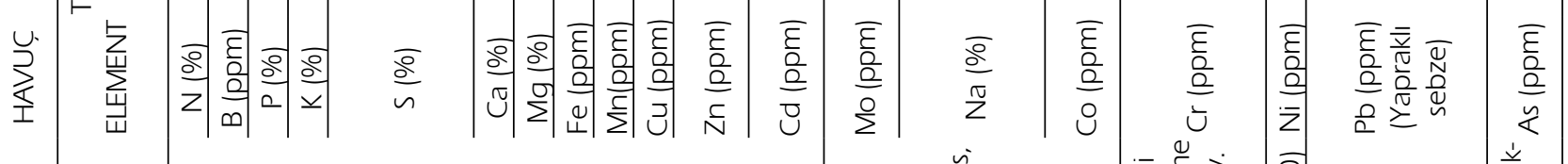

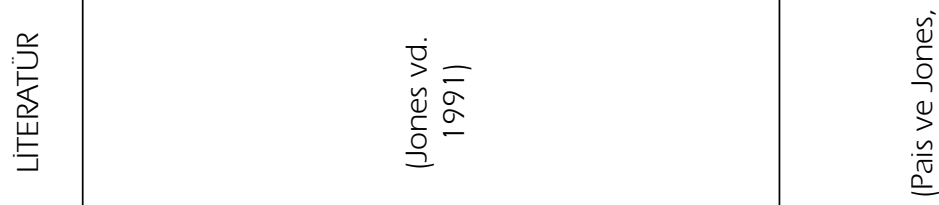

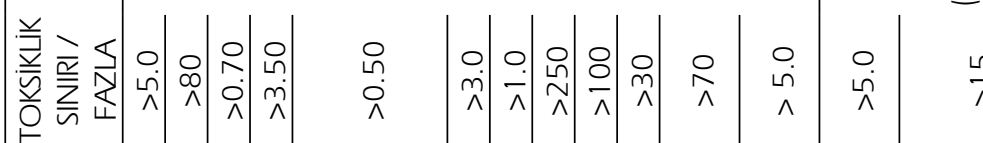

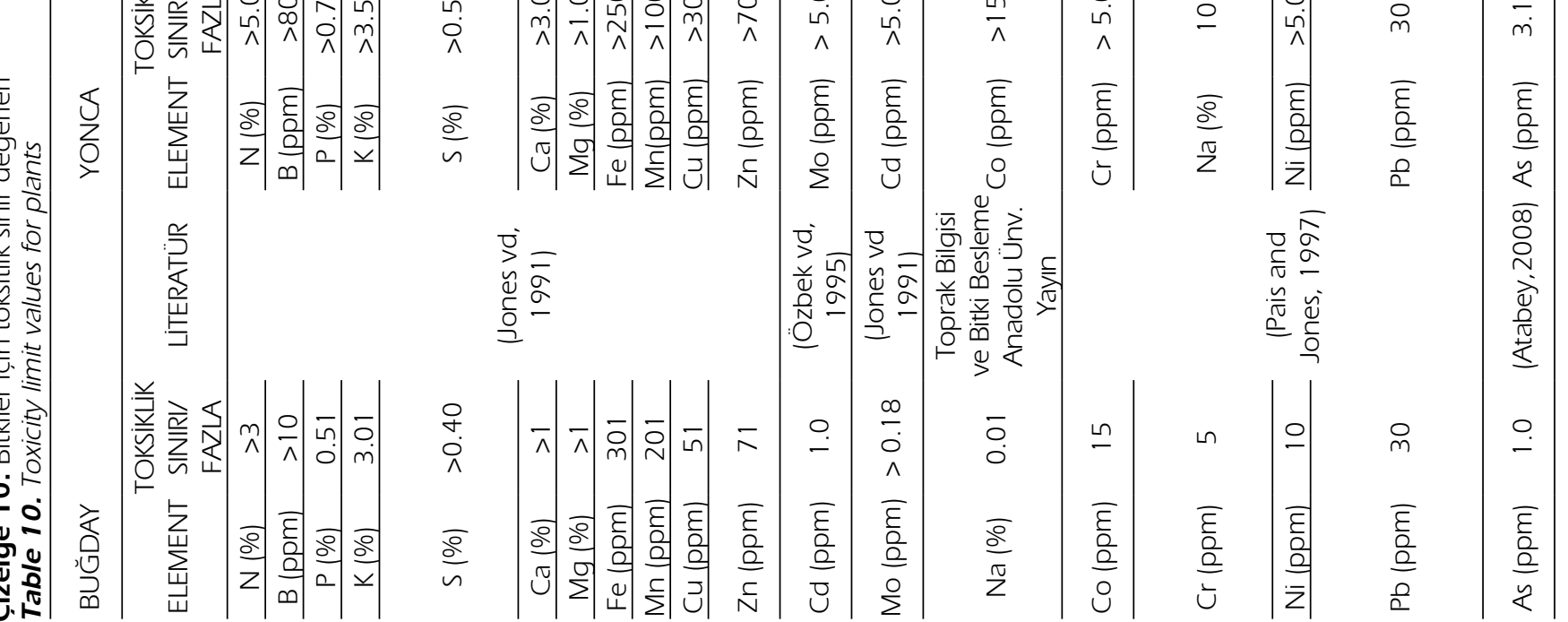

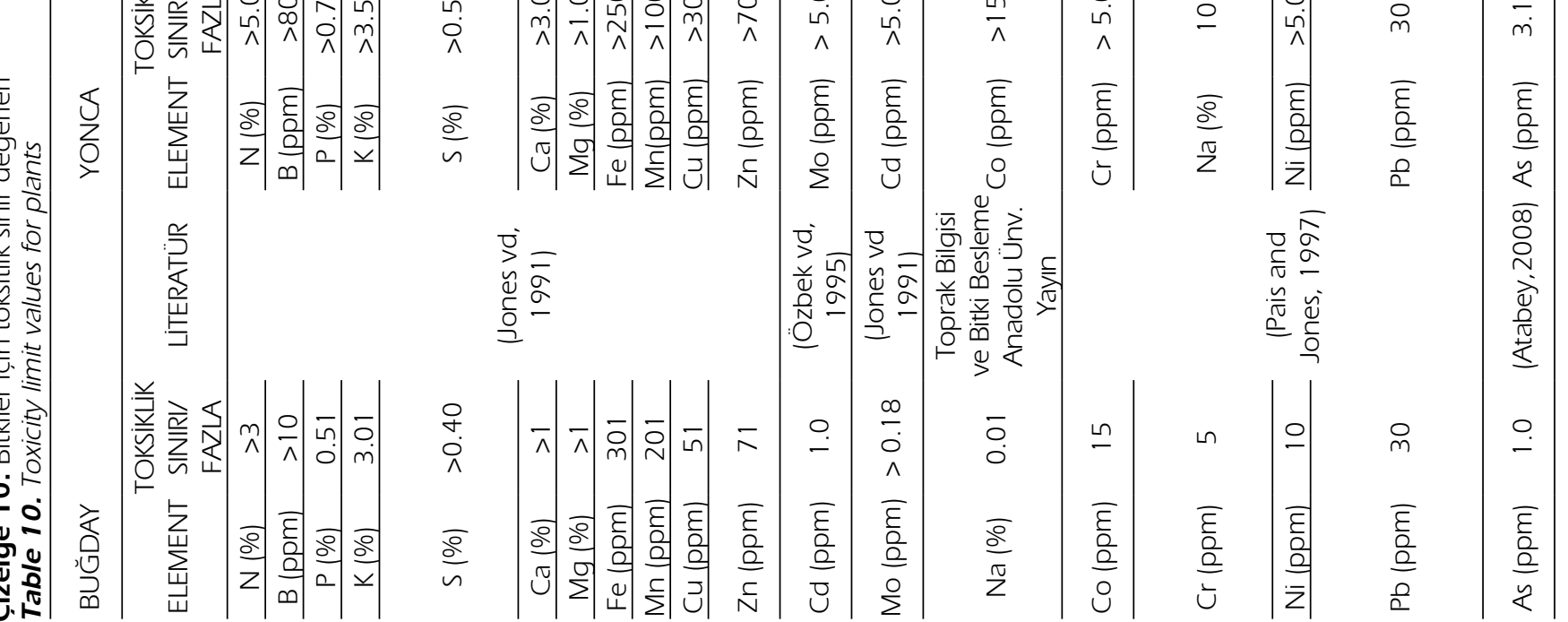

峁

文

$\frac{n}{\sqrt{v}}$

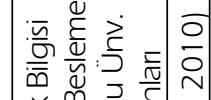

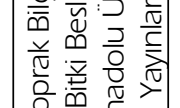

竞竞离

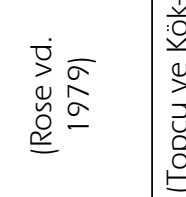

产 


\section{SONUC̣LAR}

Çalıșma alanı içerisinde bulanan sulardan elde edilen bulgular tarımsal sulama suyu kalite kriterlerine göre değerlendirilmiș ve buna göre; jeotermal kaynaklar ve deșarj edilen atık suların sulama sezonu öncesi ve sulama sezonu sonrası dönemlerinde sıcaklık, elektriksel iletkenlik (Ec), sodyum adsorbsiyon oranı (SAR), klorür $\left(\mathrm{Cl}^{-}\right)$, sülfat $\left(\mathrm{SO}_{4}^{-}\right)$, toplam tuz konsantrasyonu, bor ve tuzluluk alkalilik sınıfları açısından $V$. Sınıf kullanılamaz su kalitesinde olduğu belirlenmiștir. Bu sulara ait ağır metal ve iz elementlerden; Molibden (Mo), Bor (B) ve Arsenik (As) konsantrasyon düzeyleri de sulama sularında bulunması gereken limit değerlerin üzerinde tespit edilmiștir. Jeotermal kaynak ve atık suların bünyesinde bu kadar yüksek düzeylerde bulunan elementler, karıștığı İlhan deresi su örneklerine de yansımıs durumdadır. Buna göre; jeotermal kaynakların etkisi altında bulunmayan dere suları tarımsal sulama suyu kalite kriterlerini sağlamıș olup, \% 83.3-91.6 oranında sulama suyu kullanılabilirlik düzeyine sahip olmalarına rağmen, jeotermal kaynakların etkisi altında bulunan ve deșarj edilen noktalardan itibaren yer alan dere sularında ise, $\mathrm{pH}$, elektriksel iletkenlik (Ec), sodyum adsorbsiyon oranı (SAR), klorür $\left(\mathrm{Cl}^{-}\right)$, sülfat $\left(\mathrm{SO}^{-}\right)$, toplam tuz konsantrasyonu, bor ve tuzluluk alkalilik sınıfları açısından jeotermal kaynaklarla paralellik göstermekte olup, V. Sınıf sulama suyu kalitesinde ve $\%$ 33.3-41.6'lık sulama suyu kullanılabilirlik oranlarına sahip oldukları tespit edilmiștir.. Dere sularında gözlenen Mo, $B$ ve As konsantrasyon düzeyleri de yine sulama sularında bulunması gereken limitlerin üzerinde olup, bu suların jeotermal kaynak ve atık sulardan etkilendiği açıkça görülmektedir.

Çalıșma alanındaki jeotermal saha içerisinde içme suyu olarak kullanılan suların, değerlendirilmesinde; Arsenik düzeyinin normal limitlerin 3-23 katı, Bor düzeyinin ise 6-8 katı daha fazla olduğu sonucuna varılmıștır.

Sulama suyu kalitesi olarak kullanılamaz durumda bulunan bu sularla sulanan tarımsal ürünlerin aksamlarında bazı ağır metal ve iz elementlerin kirlilik boyutunda birikim sağlandığı görülmüștür. Buna göre; Buğday_yaprak 'ta N, B, Cd, Mo, Na, Cr; Buğday_Kök'te B, Fe, Cd, $\mathrm{Mo}, \mathrm{Na}, \mathrm{Cr}, \mathrm{As}$; Domates_Yaprak'ta N, S, Ca, $\mathrm{Fe}, \mathrm{Na}$; Șekerpancarı_Yaprak'ta S, Fe, Cu, Na; Șekerpancarı_Kök'te S ve Na; Havuç_Yaprak'ta N,
B, S, Mo, Na, Cr, Pb ve As; Havuç_Kök'te S, Mo, $\mathrm{Na}, \mathrm{Pb}$ ve As; Yonca_Yaprak'ta N ve S elementlerce birikim gözlenirken Yonca_Gövde'de ise herhangi bir element açısından birikme gözlenmemiștir.

\section{TEȘEKKÜR}

Bu çalıșma TAGEM/TSKAD/15/A13/ P08/07 nolu proje kapsamında yürütülmüștür. Desteklerinden dolayı TAGEM' e teșekkür ederiz.

\section{KAYNAKLAR}

Akman Y, Ketenoğlu O, Evren H, Kurt L, Düzenli S (2000). Çevre kirliliği, çevre biyolojisi. Palme Yayıncılık, Ankara.

Allen RG, Pereira LS, Raes D, Smith M (1998). Crop evapotranspiration guidelines for computing crop water requirements. FAO Irrigation and drainage paper 56. Food and Agriculture Organization, Rome.

Anonim (1991). Su Kirliliği Kontrolu Yönetmeliği Teknik Usuller Tebliği, Resmi Gazete sayı: 20748, Ankara.

Anonim (2004). Su Kirliliği Kontrolu Yönetmeliği Teknik Usuller Tebliği, Resmi Gazete sayı: 25687, Ankara.

Ayers RS, Westcot DW (1989). Water quality for agriculture.FAO, Irrigation and Drainage pp 29, Rev.1, p. 174 .

Birkle P, Merkel B (2000). Environmental impact by spill of geothermal fluids at the geothermal field of Los Azufers, Michoacan Mexico. Water Air and Soil Polution, 124 (3-4), 371-410.

Brohi A, Akgün A, Rüștü M, Sabit K.E (1 994). Bitki Besleme. Gaziosmanpașa Üniversitesi Ziraat Fakültesi Yayınları:4, Kitaplar Serisi:4, Tokat.

Brooks RR (1983). Biological methods of prospecting for minerals, John Willey and Sons, NewYork, s. 332.

Camgöz B, Saç MM, Bolca M, Özen F, Oruç ÖE, Demirel $\mathrm{N}$ (2010). Termal suların radyoaktivite ve kimyasal içeriklerinin incelenmesi; İzmir, Seferihisar bölgesi örneği, Ekoloji Dergisi, 19(76):78-87.

Codex Alimentarius Commission (2011). Codex Alimentarius Commission (CAC), http://mww.fao.org/faowho-codexalimentarius/en/

Dudka S, Piotrovvska M, Chlopecka A,Witek T (1995). Trace metal contamination of soils and plants by the mining and smelting industry in upper silesia, South Poland, Journal of Geochemical Exploration, 52. 237-250.

Edwards DG (1971). Concepts of essentiality and function of nutrients.

Eroğlu V (2008). Ülkemizde termal, maden suları kaynakları ve kullanımı. Termal ve Maden Suları Konferansı, 24-25 Nisan, Afyonkarahisar.

Eșder T (1981). Türkiye jeotermal enerji kaynakları ve seracılıktaki önemi. I. Türkiye Seracılık Kongresi, Etibank Matbaası, 81-108, Antalya. 
Jones Jr. JB, Wolf B, Mills HA (1991). Plant analysis handbook micro-macro Publishing inc.

Köksoy M, Topçu S (1976). Jeokimyasal prospeksiyonun tanıtımı ve laboratuar teknikleri. M.T.A. Eğitim Serisi Kitapları, 16, p. 96.

Mills H.A, Jones Jr. J.B (1996). Plant analysis handbook II. MicroMacro Publishing,

Okcu M, Tozlu E, Kumlay AM, Pehluvan M (2009). Ağır metallerin bitkiler üzerine etkileri. Alınteri 17 (B): 14-26.

Özbek H, Kaya Z, Gök M, Kaptan H (1995). Toprak bilimi. Cukurova Üniversitesi Ziraat Fakültesi, Genel Yayın No: 73, Ders Kitapları Yayın No: 16, Adana.
Pais I, Jones Jr., JB (1997). The Handbook of trace elements, St. Lucie Pres, Boca Raton, Fla., pp. 223.

Rose AW, Hawkens HE, Webb JS (1979). Geochemistry in mineral exploration (2nd edition). Academic Press, London.

TSE (1987). TS-266 İçme suyu standartları, Türk Standartlar Enstitüsü, Ankara.

USEPA (2001). Drinking water arsenic rule history. https:// www.epa.gov/dwreginfo/drinking-water-arsenic-rule-history.

WHO (1993). Guidelines for Drinking-water Quality, set up in Geneva Read more: http://www.lenntech.com/ applications/drinking/standards/who-s-drinking-waterstandards.htm\#ixzz4oPJ2H7q4. 